\title{
Development of coconut-based floating structure for stand-alone solar PV system in the tropics
}

\begin{abstract}
The use of plastics and composite materials as the base structure for a floating solar photovoltaic system commonly known as floatovoltaic system can cause negative impact to the environment especially the aquatic life and human. Additive materials are infused to form the plastics by which giving adverse effect to our metabolism. Despite the fact that the plastics are durable, to create and recycle it will produce toxic materials of many kinds in addition to the higher expenses for floatovoltaic installation. The unique approach of floatovoltaic is further discussed withstanding the continuous constraint of limited and suitable land for solar PV farms. This paper presents field analysis of the development of coconut-trunk as the base structure for a floatovoltaic system with regards to the environmental impact. A framework based on the density and buoyancy of the coconut trunk material is considered for the design
\end{abstract}

Keyword: Coconut-based; Floating structure; Stand-alone solar; PV system 